\title{
CENTRALIZÁCIÓS LÉPÉSEK - AZ ERŐS ÁLLAM ESZMÉJE
}

\author{
Szilágyi Emese $e^{10}$
}

Az elmúlt öt évben szemtanúi lehettünk az állam szerepéröl és feladatáról szóló gondolkodás szignifikáns megváltozásának. Az elméleti diskurzus középpontjában a New Public Management (NPM) ideáljának, illetve az ennek idönként szinonimájaként használt „goodgovernance” elméletnek ${ }^{11}$ az elvetése, és ezzel párhuzamosan a neoweberiánus állameszmény elötérbe kerülése, illetve a ,goodgovernment” jelszava állt. Az új teoretikus megközelitéseket hamarosan tettek is követték, azaz megkezdödött a közigazgatás reformja, illetve a közszolgáltatások rendszerének átalakitása Az elképzeléseket a 2011 júniusában bemutatott Magyary Zoltán Közigazgatás-fejlesztési Program ${ }^{12}$ volt hivatott keretbe foglalni, azonban - ahogyan arra Navracsics Tibor, akkori közigazgatási és igazságügyi miniszter is rámutatott - a központi államigazgatás átalakitása már 2010 júliusában megkezdödött az új minisztériumi rendszer kialakításával. ${ }^{13}$

Az alábbi bejegyzésben elsö lépésként röviden felvázolom a neoweberiánus elmélet leglényegesebb elemeit, majd ezt összevetem a közigazgatási rendszer és a közszolgáltatások átszervezésének megvalósulásával. Az irással azt az állítást igyekszem alátámasztani, amely szerint a hazai reformok valójában nem egyeztethetöek össze a neoweberi elképzelésekkel.

\section{A neoweberiánus ideál}

A neoweberiánus állameszmény és a goodgovernment elképzelések még a 2010-es kormányváltás előtt, mintegy a 2008-ban kezdődő gazdasági világválságra adott egyféle reakcióként jelentek meg a hazai közpolitikai diskurzusban (elsőként a Századvég think tank - től: Jó kormányzás és az állam 2008). A neoweberiánus elgondolás hazai változata a New Public Management mozgalommal szemben pozícionálja magát. Az NPM a közszektor hatékonyságának, eredményességének és fogyasztó-orientációjának növelését célozza, az állam leépítésének és a privatizációnak a segítségével; továbbá a piaci törvényszerüségek átvételével. Az NPM a közszektor müködtetésében is sürgeti a magánvállalati szektorban alkalmazott technikáknak, megközelítéseknek - azaz a menedzser-szemléletnek - az átvételét. Ezzel szemben a neoweberiánus teória abból az előfeltevésből indul ki, amely szerint a közigazgatás és a közszolgáltatások átfogó reformját, illetve az állam és a piac egymáshoz való viszonyának radikális újragondolását célul tüző New Public Management mozgalom Kelet-Közép-Európában nem váltotta be a hozzájuk füzött reményeket. Ennek oka részen az, hogy hiányoznak azok a peremfeltételek - elsősorban a kiszámítható források, a közszolgálat ethosza, a hiteles szakpolitika-alkotás -, amelyek alapvetőek volnának az átalakítások sikeres végrehajtásához. ${ }^{14}$

A neoweberi állammodell célja szerint „,a közjó homályos eszméjét a demokrácia normatív tartalma tölti ki.". ${ }^{15} \mathrm{Az}$ elmélet egyik fontos alapvetése, hogy az államot ismételten a

\footnotetext{
${ }^{10}$ Szilágyi Emese,tudományos segédmunkatárs; MTA TK JTI.

${ }^{11}$ FRIVALDSZKY János (2012): A jó kormányzás és a helyes közpolitika formálásának aktuális összefüggéseiröl. In: Szigeti Szabolcs - Frivaldszky János (szerk.): A jó kormányzásról. Elmélet és kihívások. Budapest: LHarmattan Kiadó, 56.

${ }^{12} \mathrm{http}$ ://magyaryprogram.kormany.hu/admin/download/d/2c/40000/Magyary\%20kozig\%20fejlesztesi\%20progra m\%202012\%20A4.pdf (Letöltés: 2015. szeptember 15.)

${ }^{13}$ NAVRACSICS Tibor (2013): A közigazgatás korszerüsítésének programja Pro PublicoBono. 2013/2. sz. 53.

${ }^{14}$ G. FODOR Gábor - STUMPF István (2008): A ,jó kormányzás” két értelme. Nemzeti Érdek. 2007/3. sz. 13.

${ }^{15}$ G. FODOR Gábor - STUMPF István (2007): Neoweberi állam és jó kormányzás. Nemzeti érdek. 2008/2. sz. 83.
} 
középpontba helyező modell „összekapcsolja a jó kormányzás igényét a demokrácia normatív tartalmával." A demokrácia legfontosabb értéke az érvelés szerint az, hogy garantálja azokat a feltételeket, amelyek között az egyén saját értékelése szerinti jó és ésszerü élet elérhető mindenki számára; az ehhez szükséges körülményeket pedig egy aktornak, nevezetesen az államnak szükséges garantálnia. $^{16}$

A teória másik tézise, hogy az NPM ideológiája annyira kiüresíti az állam eszményét, hogy végső soron a kormányzatnak a társadalom által történő felelősségre vonhatósága, elszámoltathatósága is elenyészik. Így pedig végső soron ellehetetlenül a demokratikus visszacsatolás mechanizmusa. Ezzel szemben amennyiben az állam a jó kormányzás feladatait is magára vállalja, akkor megvalósul a kormányzati teljesítmény értékelhetősége, a kormány pedig felelősségre vonhatóvá, azaz elszámoltathatóvá válik. ${ }^{17}$

A neoweberi elméletet számos írásban népszerüsítette G. Fodor Gábor és Stumpf István. Ök annak lényegét így foglalták össze: „,a neoweberi állam az új közmenedzsment torzulásaira adott válasz, annak tudatában, hogy a megváltozott körülmények között nem lehetséges a klasszikus weberi államhoz való visszatérés." ${ }^{18}$ Írásuk szerint a cél az NPM irányzatra jellemző rugalmasság ötvözése a weberiánus megfontolásokkal.

A weberi elemek tehát:

- az állam megerősítés

- a gazdasági növekedés biztosítása céljából;

- képviseleti demokrácia szintjeinek megerősítése;

- jogszerüség és normativitás, az elszámoltathatóság és politikai felelősség érvényesítésének lehetősége, az alkotmányosság, a joguralom elvének tiszteletben tartása;

- a köztisztviselői ethosz erősítése.

Ami pedig a teóriát „,neo”-vá teszi:

- polgárbarát és eredményorientált jelleg, amelynek hozománya a közigazgatás minőségének és szolgáltatási jellegének erősödése;

- a civil szférával való kapcsolatok erősítése, amely kiegészítője a képviseleti demokráciának;

- professzionalizáció szakmai továbbképzéssel, teljesítményértékelési rendszerrel.

Ezeknek az átalakításoknak az eredményeként - érvelésük szerint - fokozottabb gazdasági növekedés érhető el; megvalósítható a normakövető kormányzás, az elszámoltathatóság és a politikai felelősségre vonhatóság; visszaszorítható a korrupció mind a köztisztviselői karon belül, mind pedig a statecapture jelensége (azaz, amikor az államot gazdasági érdekcsoportok ejtik foglyul; ez álláspontjuk szerint kifejezetten a NPM ideológiájának egyik velejárója ${ }^{19}$; csökkenthető a szegénység; és a civil szférával való fokozottabb kapcsolattartás eredményeként kiszélesíthető a demokrácia. ${ }^{20}$

A közigazgatás „korszerüsítésének” egyik legfontosabb, nyilvánosan is elérhető keretdokumentuma a Magyary Program - amint arról már szó esett. Ebben, illetve a Navracsics Tibor által hozzá füzött magyarázatban is tetten érhetőek a neoweberi gondolkodás egyes elemei:

- így az állam és a polgár hagyományos viszonyrendszerének átalakítására irányuló deklarációk, azaz az „alattvalói” attitűd helyett a mellérendeltségi, partneri viszony erősítése;

- az átláthatóság megteremtése szervezeti kataszter segítségével;

\footnotetext{
${ }^{16} \mathrm{G}$. FODOR Gábor - STUMPF István (2008): i.m.: 10.

${ }^{17}$ G. FODOR Gábor - STUMPF István (2007):i.m.: 81.

${ }^{18}$ G. FODOR Gábor - STUMPF István (2008): i.m.: 15.

${ }^{19}$ G. FODOR Gábor - STUMPF István (2007):i.m.: 79,81.

${ }^{20} \mathrm{G}$. FODOR Gábor - STUMPF István (2008): i.m.: 15-18.
} 
- a kormányablakok rendszere, azaz az egyablakos, állampolgár-barát ügyintézés;

- a közigazgatási ethosz visszaállítása az életpályamodell felépítésével és a köztisztviselöi képzési rendszer átalakításával, teljesítményértékelési rendszer bevezetésével. $^{21}$

\section{Gyakorlati megvalósulás}

Amennyiben azonban részletesebben szemügyre vesszük az egyes konkrét kormányzati lépéseket, láthatjuk, hogy a közigazgatást - és általában az állam szerepét - érintő számos változtatás nem korrelál, ellenkezőleg, épp, hogy ellentétben áll a neoweberiánus elképzelésekkel. Ennek az állításnak az alátámasztására a továbbiakban nagyon röviden áttekintek három reformlépést: az önkormányzati rendszer átalakítását, a közoktatást érintő módosításokat és a víziközmü-szolgáltatás átszervezésének tapasztalatait.

\section{Az önkormányzati rendszer átalakítása.}

Az új rendszer alapvető jellegzetessége az önkormányzatiság leépítése, a centralizáció, amely mind a feladat- és hatáskörökre, mind pedig az ahhoz tartozó pénzügyi eszközökre vonatkozik. A legfontosabb tartalmi változások: az önkormányzati kötelezően ellátandó feladatok körének csökkenése; az államigazgatási hatósági feladatok jelentős részének kikerülése az önkormányzati rendszerböl; a közszolgáltatási funkcióknak a megyei önkormányzatoktól történő elvonása; kötelező társulás bevezetése bizonyos esetekre; szigorodó törvényességi felügyelet; szigorodó gazdálkodási szabályok; a feladatfinanszírozás bevezetése; valamint a polgármester szerepének erősödése a képviselö-testülettel szemben. ${ }^{22}$ Vagyis, a neoweberi modell eszményeivel épp ellentétes változás történt: a képviseleti demokrácia lokális szintjeinek erösitése helyett egyoldalú centralizációra került sor.

\section{Módosítások a közoktatásban}

Az oktatáspolitikai kormányzat 2012-ben kezdte el a közoktatás rendszerének átalakítását. Az átalakítás kulcseleme, hogy a köznevelési funkciót az állam vette át a helyi önkormányzatoktól. A deklarált célok a hatékonyabb müködés, az oktatás egységes minőségének biztosítása és a felzárkóztatás. Ennek jegyében a közoktatási intézmények állami müködtetésűvé váltak, a GDP-arányos költségvetési ráfordítás csökkent, azonban megtörtént a vitatott eredményességü pedagógus életpályamodell bevezetése. Ahogyan arra Pénzes is rámutat, a helyi kezdeményezések, a civil szféra kiszorul az oktatás szervezéséből. Ez pedig meröben ellentétes a neoweberiánus eszménykép azon elemével, amely szerint a demokratikus döntéshozatal a civil szféra intézményesitett bevonásával megerösitendő. Bár a hatékonyság növelése ezen a területen is általános igénnyé vált a válság hatására Európában, a helyi - adott esetben speciális - igények negligálása alapvetően szembemegy az európai trendekkel $^{23} \mathrm{~s}$ a felzárkóztatás, a társadalmi egyenlőtlenségek kiküszöbölésének célját is alááshatja.

\section{Viziközmü-szolgáltatás}

Az állam az ezidáig többé-kevésbé piaci alapon müködő szférákba is benyomul. Ezek között említhető a hulladékgazdálkodás, a kéményseprö-ipari közszolgáltatás, az energiaszektor, vagy a víziközmü-szolgáltatás jogszabályi környezetének megváltozása. Az utóbbiról elmondható, hogy az a tulajdoni rendezés és a szolgáltatás müködtetésére vonatkozó

\footnotetext{
${ }^{21}$ NAVRACSICS Tibor (2013):i.m.: 52-58.

${ }^{22}$ PÁlNÉ Kovács Ilona (2014): Az önkormányzati rendszer és a területi közigazgatás átalakulása 20102013. MTA Law WorkingPapers. 2014/2. sz. 2-3.

${ }^{23}$ Erröl bővebben ld.: Péteri Gábor (2014): Területi közszolgáltatások szabályozási modelljei: a közoktatás. In.: Horváth M. Tamás (szerk): Külön utak. Közfeladatok megoldásai. Budapest-Pécs: Dialóg Campus Kiadó.
} 
államosítási törekvéseknek az összefonódása. A témában írott elemzésükben Horváth $\mathrm{M}$. Tamás és Péteri Gábor állapítja meg, hogy vízközmü-szolgáltatások átszervezésének folyományaként a helyi önkormányzatok befolyása elöre láthatóan gyengül: „a kisebb települési önkormányzatok kevésbé lesznek képesek befolyásolni a fejlesztéseket, felújításokat, pótlásokat, a szolgáltatás minőségét". ${ }^{24}$ Ezzel párhuzamosan a fogyasztói befolyás csökkenése is tetten érhetö. Vagyis, a helyi közösség demokratikus befolyása gyengül, illetve - mivel várhatóan a társulásokban a döntéshozatal során az egyébként is nagyobb súlyú városi önkormányzatok javára billen a mérleg -a társadalmi igazságosság elérése is távolabb kerül.

Úgy tünik tehát, hogy bár az állam szerepéről való gondolkodás megváltozásában nagy szerepe volt a neoweberiánus elképzeléseknek Magyarországon, azonban a gyakorlati megvalósítás során az elméletből elvesztek azok az elemek, amelyek a modell valódi újdonságát adhatnák. Ami megvalósult az nem más, mint egyoldalú és nyers centralizáció, az állam szerepének erös növelése, de a demokratikus participáció kiegyensúlyozó szerepének és az egyéni sajátosságok figyelembe vételének garantálása nélkül.

\footnotetext{
${ }^{24}$ Horváth M. Tamás - Péteri Gábor (2013): Nem folyik az többé vissza. Az állam szerepének átalakulása a vízközmü-szolgáltatásban. In: Valentiny Pál - Kiss Ferenc László - Nagy Csongor István (szerk.): Verseny és szabályozás. Budapest: MTA KRTK Közgazdaság-tudományi Intézet. 177-189.
} 